\title{
DA TRANSGRESSÃO À PUREZA: SABER, PODER E POLÍTICA NO ÉDIPO DE FOUCAULT*
}

\author{
FABIANO INCERTI ${ }^{* *}$ \\ doi: 10.11144/Javeriana.uph36-72.dtpf
}

\section{RESUMO}

Foucault reconhece, em suas análises da década de 1970, que Édipo significa uma ruptura entre o saber específico e o poder político. Para ele, há tanto em Platão como em Sófocles resistência ao modelo social no qual o soberano detinha o poder da mântica, da justiça e da vida política. $\mathrm{O}$ que deve desaparecer, para ambos, é a imagem do rei sábio, que sustenta, governa, pilota, endireita a cidade e a livra da peste e da fome, e a sua versão rejuvenescida, o tirano, que salva a cidade, mas o faz desviando-se do oráculo dos deuses. A história edipiana é, portanto, a passagem do poder político ligado às transgressões e às lutas para o poder político entendido, desde então, como pureza, cegueira e ignorância.

Palavras-chave: saber; poder; política; Édipo-Rei, Michel Foucault

\footnotetext{
Este artigo é resultado da investigação desenvolvida no estágio pós-doutoral na Faculdade de Ciências Sociais da Universidade de Buenos Aires. Alguns trechos foram anteriormente elaborados na minha tese de doutorado $O$ visivel e o sonoro em Édipo-Rei: uma análise foucaultiana. Pontificia Universidade Católica de São Paulo, 2013 (inédita).

" Pontificia Universidade Católica do Paraná.

Correo electrónico: fabiano.incerti@yahoo.com

Para citar este artículo: Incerti, F. (2019). Da transgressão à pureza: saber, poder e política no Édipo de Foucault. Universitas Philosophica, 36(72), 305-327. ISSN 0120-5323, ISSN en línea 23462426. doi: 10.11144/Javeriana.uph36-72.dtpf
} 


\title{
FROM TRANSGRESSION TO PURITY: KNOWLEDGE, POWER AND POLITICS IN FOUCAULT'S OEDIPUS
}

\begin{abstract}
Foucault acknowledges, in his analyses of the 1970s, that Oedipus means a rupture between specific knowledge and political power. For him, there is, both in Plato and Sophocles, resistance to the social model in which the sovereign held the power of mantica, justice and political life. For both, what must disappear is the image of the wise king, who upholds, governs, pilots, and straightens out the city, releasing it from the plague and famine; and his rejuvenated version, the tyrant, who saves the city, but does so by turning away from the oracle of the gods. The Oedipal story is, therefore, the passage of political power linked to the transgressions and struggles for political power understood, since then, as purity, blindness and ignorance.
\end{abstract}

Keywords: knowledge; power; politics; Oedipus-King, Michel Foucault 
POR PELO MENOS TRÊS DÉCADAS, o único pronunciamento conhecido e amplamente estudado de Michel Foucault sobre o Édipo-Rei foi aquele realizado no Brasil entre os dias 21 e 25 de maio de 1973, e publicado um ano mais tarde nos cadernos da Pontifícia Universidade Católica do Rio de Janeiro com o título $A$ verdade e as formas jurídicas. Somente 35 anos depois, em 2008, o grande público pôde ter acesso a um novo parecer do pensador francês sobre o mais famoso drama do teatro grego, com a publicação do curso Le gouvernement de soi et des autres, proferido entre os anos de 1982 e 1983.

Em 2011, devido ao lançamento do curso de 1970-1971, Leģons sur la volonté de savoir, passa-se a conhecer a aula de 17 de março de 1971, a primeira de Foucault exclusivamente sobre o assunto, juntamente com um dos mais importantes e completos estudos seus sobre Édipo-Rei, chamado Le savoir d'CEdipe, proferido em março de 1972 na State University of New York e, em outubro do mesmo ano, na Cornell University, ambas nos Estados Unidos. Em 2012(a), é publicado o curso de 1979-1980, Du gouvernement des vivants, no qual o pensador francês dedica especialmente as aulas de 16 e 23 de janeiro de 1981 ao herói de Sófocles. E, por fim, um texto muito significativo é a conferência de 28 de abril de 1981, editada pela Universidade de Louvain na Bélgica também em 2012(b), sob o título Mal faire, dire vrai. Fonction de l’aveu en justice.

A publicação da maioria dos cursos do pensador francês proferidos no Collège de France entre os anos de 1970 e 1984, e de outras conferências realizadas em diferentes universidades do mundo no mesmo período, mostra que as análises realizadas por ele acerca da tragédia de Édipo são mais recorrentes do que se imaginava. A visão geral que temos atualmente, tendo por base os textos publicados, nos leva a uma constatação: as leituras de Foucault a respeito de Édipo iniciam no decorrer de suas pesquisas conhecidas como genealógicas e se estendem para seus últimos escritos, que tratam das questões concernentes à constituição do sujeito ético. Nesse movimento, três ideias atravessam suas análises e se colocam como fios condutores: 1) Édipo é uma história sobre a descoberta progressiva da verdade, a partir da "lei das metades"; 2) trata-se do primeiro testemunho das práticas judiciárias gregas; 3 ) é uma tragédia do saber, do poder e do excesso. 
Por outro lado, é relevante observar que, no interior da história de Sófocles, há uma série de outros conceitos discutidos pelo pensador francês, diretamente relacionados às investigações desenvolvidas por ele, especialmente na década de 1980. Destaca-se, por exemplo, a noção de dizer-verdadeiro, no curso de 1979-1980; de confissão, na conferência de 1981; e de parrêsia, no curso de 1982-1983.

Tendo por base esse breve itinerário intelectual de Foucault, atravessado pelas leituras de Édipo-Rei, pretendemos com este trabalho analisar, a partir dos três textos da década de 1970 já citados ${ }^{1}$, de que forma a peça de Sófocles se configura para o pensador francês como o ponto de emergência de um longo processo de decomposição que foi se estabelecendo, desde a Grécia, da relação entre saber e poder, impondo, sobre a cultura ocidental, a ruptura entre poder político e o saber.

\section{Crítica ao universalismo da psicanálise e a influência nietzschiana}

No DECORRER DE SUA TRAJETÓRIA INTELECTUAL, Foucault manteve com a psicanálise um diálogo dinâmico, intenso e, por quê não dizer complexo, na medida em que variou entre momentos de aproximação e de afastamento ${ }^{2}$. Levando

1 Aula de 17 de março de 1971, do curso Leçons sur la volonté de savoir, conferência Le savoir d'CEdipe, de 1972 e a segunda conferência de 1973, A verdade e as formas jurídicas.

2 Ernani Chaves (2014), no prefácio à edição brasileira do livro $A$ psicanálise é um exercício espiritual? de Jean Allouch afirma que "[...] O leitor e o pesquisador interessados podem dispor, hoje, da possibilidade concreta de reconstruir, à maneira de Foucault, isto é, arqueologicamente, seu longo trajeto de confrontação com a psicanálise, desde a década de 1950. Confrontação que ora o aproximou dela, que ora o afastou - como na História da loucura em 1961 -; que ora voltou a reencontrá-la com entusiasmo, como em As palavras e as coisas, em 1961, que nunca deixou de reconhecê-la na sua ruptura com a psiquiatria, como na quinta conferência de $A$ verdade e as formas jurídicas, proferida em maio de 1973, no Rio de Janeiro, mas que não deixou de incluí-la no 'dispositivo psi', que rege, em grande parte, a sociedade disciplinar em Vigiar e punir, de 1975; ou ainda em $A$ vontade de saber, primeiro volume da História da sexualidade, de 1976, no qual se reúnem novamente a crítica contundente à relação estabelecida por Lacan entre o desejo e a lei, e mesmo à relação entre poder e repressão, mas também o elogio à eficácia da crítica psicanalítica da teoria da degenerescência na época do nazismo. Mesmo o prefácio a Uso dos prazeres, o segundo volume da História da sexualidade, publicado em maio de 1984, ou seja, um mês antes de sua morte, continua criticando a consequência que significaria continuar insistindo num 'pensamento comum', que faz da sexualidade um 'invariante' e considera suas formas históricas singulares apenas os efeitos 'dos mecanismos diversos de repressão a que se encontra exposta toda sociedade. Com isso, continua 
em conta tal perspectiva, quando nos detemos com um olhar mais atento nos três textos de Foucault da década de 1970, um ponto se revela comum: eles contêm uma crítica à interpretação universalista dada por Freud à trama que envolve o protagonista da peça de Sófocles ${ }^{3}$. Em tais críticas o pensador francês explica, já em sua primeira aula sobre Édipo, que a fábula de Sófocles, antes de significar o destino universal de nossos desejos, trata, sobretudo, de um sistema complexo de coações que sustenta, desde a Antiguidade grega, o discurso sobre a verdade no Ocidente. Coações que, por um lado, se expressam na exigência política, jurídica e religiosa de converter o acontecimento num fato conservado definitivamente por meio da comprovação das testemunhas e, por outro, na exigência, também política, jurídica e religiosa de distribuição do poder sobre o saber, permitindo o acesso à verdade somente aos detentores da sabedoria e da pureza.

O "engano de Freud" (Foucault, 2014, p. 177) estaria exatamente no fato de considerar que Édipo se situa no encontro entre desejo e verdade, avançando para a ideia da existência de formas universais de desejo, esquecendo com isso, que a tragédia discorre sobre a coerção histórica e política que pesa sobre os sistemas ocidentais de verdade. Para Foucault, se de alguma maneira estamos submetidos a uma determinação edipiana, essa não é no nível do desejo, mas, sim, no de nosso discurso verdadeiro.

Na conferência de 1972, ainda que de maneira breve e sem mencionar Freud, Foucault (2014) endossa as críticas realizadas no ano anterior. Nelas, o pensador francês aponta que ao invés de reconhecermos a história do herói trágico como uma fábula dos excessos, onde tudo sobra - pais, irmãos, filhos -, ela é recorrentemente lida como ignorância, culpa, inconsciência e desejo, no qual o saber está sempre relacionado à consciência. Nesse sentido, desde as análises de Freud, para ele houve uma negativização da história de Édipo, colocando o foco na problemática da "carência do saber" (p. 236).

Em 1973, essa crítica a Freud se estende também ao poder médico e psicanalítico que opera sobre o desejo a partir do "Complexo de Édipo". Por meio da

Foucault, 'coloca-se fora do campo histórico o desejo e o sujeito do desejo', fazendo com que a 'forma geral da interdição dê conta do que pode haver de histórico na sexualidade”' (pp. 12-13).

3 As críticas à universalização que a psicanálise freudiana faz de Édipo-Rei não serão mais um problema nas análises que o pensador francês desenvolve da peça nos escritos da década de 1980 . 
reflexão do L'Anti-CEdipe, de Deleuze e Guattari (1972), Foucault (2002) mostra como a teoria freudiana acerca do herói de Sófocles significou para psicanalistas e psiquiatras um aparelho de contenção do desejo, tornando-se uma forma particular de estabelecimento das relações entre saber e poder, conhecimento e política:

Édipo não seria, pois, uma verdade de natureza, mas um instrumento de limitação e coação que os psicanalistas, a partir de Freud, utilizam para conter o desejo e fazê-lo entrar numa estrutura familiar definida por nossa sociedade em determinado momento (p. 29).

É importante considerar que ao denunciar o imperialismo de Édipo, derivado da aceitação moderna do triângulo edípico freudiano, pai-mãe-filho e, ao abordar as condições da pré-subjetividade, a noção de inconsciente e a relação da psicanálise com estruturas econômico-políticas, L'Anti-OEdipe se configura como uma crítica pós-nietzschiana ao que os autores consideram uma das fontes dos males sociais e individuais da sociedade ocidental: o modelo de família “edipizada”. Deleuze (2003) afirma que de lá nascem, dentre outras coisas, as estruturas de repressão, a obsessão em relação ao poder patriarcal, a sexualidade possessiva, o individualismo fragmentado e neurótico e, por fim, o capitalismo (pp. 25-52).

A partir disso, e a exemplo do que já tinha feito Jean-Pierre Vernant (1999b) em seu artigo "Édipo sem complexo" de 1967 (pp. 53-71)4, vê-se a clara intenção de Foucault (2002) de deslocar o centro da história da problemática do incesto (p. 130) - marca indelével da interpretação psicanalítica do texto trágico -, para a compreensão de uma trama que se desenvolve em torno do campo jurídico e religioso, por meio de uma série de procedimentos perfeitamente representativos da Grécia clássica, e que evocam o sentido profundo das mudanças que os campos do direito e da política atravessavam na época em que foi apresentada a tragédia. Identificamos novamente tal perspectiva, quando o pensador francês entende

4 Ademais, além de Vernant, há um grupo significativo de filólogos e helenistas que relacionaram a tragédia grega às questões jurídicas, dos quais destacam-se Louis Gernet (1968), com Droit et institutions em Grèce Antique; Werner Jaeger (1953), com "Alabanza de la ley: los orígenes de la filosofía del derecho y los griegos"; Pierre Vidal-Naquet (1999) com "Édipo em Atenas" de 1973; e Marcel Detienne (1967), com Les Maîtres de Vérité dans da Gréce archaïque. 
que Édipo é "fundamentalmente o primeiro testemunho que temos das práticas judiciárias gregas", sendo "um procedimento de pesquisa a verdade que obedece exatamente às práticas judiciárias gregas dessa época” (Foucault, 2002, p. 31).

Se, por um lado, Foucault se mostra crítico da interpretação universalista de Freud, por outro torna-se inegável a influência de Nietzsche em seu trabalho, ao inserir o drama de Édipo-Rei num debate político. Constata-se isso, por exemplo, no fato de que juntamente com o significativo texto Nietzsche, a genealogia e a história (1999), de 1971, há outros dois pronunciamentos sobre o filósofo alemão que se encontram no intervalo de suas primeiras análises a respeito do herói de Sófocles. Também de 1971, há a aula "Como pensar a história da verdade com Nietzsche sem basear-se na verdade", nas Aulas sobre a vontade de saber. Curso no Collège de France (2014), pronunciada em Montreal, cujo conteúdo está muito próximo da primeira conferência realizada em 1973, na Pontifícia Universidade Católica do Rio de Janeiro.

$\mathrm{Na}$ medida em que para Foucault (2002), Sófocles, e mais tarde Platão, introduzem no Ocidente um tipo de saber que tanto impõe à verdade mensuração, constatabilidade, pureza e memória como renúncia ao poder, excluindo toda forma de luta, de excesso e de transgressão, ele encontrará em Nietzsche - potencializando principalmente o aspecto crítico e a utilização de alguns conceitos, como proveniência, emergência e invenção -, uma importante ferramenta teórica para questionar a vontade de saber que domina a cultura ocidental. Nesse sentido, o esforço do pensador francês está em mostrar que não há harmonia na relação entre sujeito e objeto, tampouco o conhecimento está inscrito, como desejo e prazer, na natureza humana. Pelo contrário, o conhecimento é instinto, invenção, decorrência da violência, da dominação, do poder e da violação (p. 18) e a relação entre sujeito e objeto é resultado de uma operação complexa, que compreende maldade, astúcia e pacto entre as paixões. O que se tem então, não é um sujeito do conhecimento, mas o reverso disso, ou seja, um sujeito dividido e descentrado em seus desejos.

Quando tal influência é levada para as análises de Édipo-Rei, Arianna Sforzini (2015) mostra como basta um olhar sobre os textos e fragmentos do jovem Nietzsche - Introdução às liçôes sobre Édipo-Rei de Sófocles (2006) e O nascimento da tragédia (1992) - para se compreender que no interior do Édipo de Foucault se encontra o Édipo de Nietzsche, pois este revela ao homem ocidental seu segredo, 
que não diz respeito ao enigma de seu desejo, mas sim de seu conhecimento (p. 174). Ela mostra que ao mesmo tempo em que é incestuoso, Édipo é aquele que resolve o enigma da Esfinge e pode fazer isso - se transformar no emblema da gnômê, da sabedoria -, precisamente porque ele é o homem que profana os interditos da natureza, que se coloca "além do bem e do mal". O saber então é essa ferida que fende a natureza e coloca em jogo toda harmonia da representação e do conhecimento. Nesse sentido, para Sforzini, o Édipo que Foucault quer questionar é exatamente esse que Nietzsche (1988) designa como "símbolo da ciência" (p. 141, nossa tradução) ${ }^{5}$, e o faz assumindo a ideia de Édipo-Rei como a encenação da vontade de saber, ou seja, a expressão da batalha da verdade que se esconde sob o nascimento do conhecimento científico, a violência que essa luta implica e as verdades outras que este saber reduziu ao silêncio.

Com Nietzsche, Foucault (2014) critica a exclusão do devir em nome de uma ordenação lógica dos fatos do passado que conduzem a um resultado objetivo. Junto com o saber sofístico e a reminiscência platônica, esse devir é a tragédia (pp. 14-18); saber excluído, que não é o resultado da conaturalidade entre desejo e conhecimento, mas antes é expressado pelo enigma, pela duplicidade: 1) um saber temível, "porque é ao mesmo tempo obscuro e promissor" (p. 14); 2); um saber que cega, "cujo olhar ofusca aqueles que fixa” (p. 14); 3) um saber que mata: "No momento [em que] recai sobre o herói, este não lhe resiste. O raio de luz e o da morte confundem-se" (p. 14).

\section{Saber e poder em Édipo-Rei: transgressóes e excessos}

NAS ANÁlises foucaultianas da DÉCADA DE 1970 acerca de Édipo-Rei, destacam-se duas características do saber que, para o pensador francês, são, ao mesmo tempo, singulares e complementares. A primeira delas trata-se da capacidade de encontrar ( $\varepsilon \dot{p} \operatorname{li} \varkappa \varepsilon \iota \nu$ ), própria de Édipo. Já nas primeiras cenas de Édipo-Rei temos evidência desse traço de personalidade. Diante do sacerdote e 
do povo, é ele quem deve encontrar ( $\varepsilon \dot{p} p \varepsilon \tilde{v}, 42)^{6}$ o socorro para curar o sofrimento que outra vez dissipa a cidade. Após cautelosa reflexão toma (ทũpı $\sigma o v, 68$ ) a única medida aceitável para o momento, que é enviar Creonte ao oráculo de Delfos. Nos versos seguintes, censura os cidadãos tebanos por não haverem, no tempo certo, tentado descobrir ( $\varepsilon \dot{\nu} \varepsilon \theta \dot{\eta} \sigma \varepsilon \tau \alpha \iota, 108)$ o assassino de Laio.

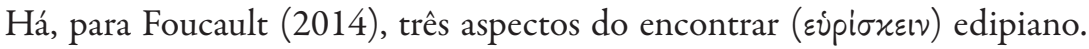
O primeiro deles se refere a um exercício solitário, no qual ele deve "descobrir" sozinho. Em sua posição de rei, ele quer "informar-se pessoalmente, encontrar pessoalmente, decidir pessoalmente" (p. 227). O segundo diz respeito a um exercício que depende necessariamente de uma testemunha (p. 227). Ao mesmo tempo em que Édipo se reconhece protagonista, ou seja, aquele que deve resolver o problema da cidade, sente-se constrangido, pois naquilo que exige o oráculo - descobrir o assassino de Laio -, ele tanto não tem a lembrança como

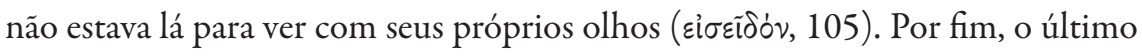
aspecto é a identificação dos elementos visíveis que unem passado e presente, que acontece exatamente a partir da busca por indícios ( $\sigma \dot{\mu} \mu \beta 0 \lambda \circ v)$, própria do nascente direito ático. Na medida em que estes indícios são desvendados, Foucault (2002) considera que eles revelam que é por seu excesso de saber, por sua obstinação pela verdade completa e pelo reconhecimento de sua identidade que Édipo cai na armadilha de seu destino.

A segunda característica, própria do texto trágico, é a circulação do saber entre os diferentes personagens da trama, estabelecendo um complexo jogo de completudes atravessado pelo poder. Para Foucault (2014), o mecanismo que rege esse deslocamento do saber é a lei das metades (loi des moitiés), que no interior da noção jurídico-religiosa grega de $\sigma \dot{u} \mu \beta 0 \lambda \circ v$, representa originalmente um sinal de reconhecimento entre os possuidores de cada uma das metades de um objeto partido em dois (p. 217). As partes quebradas, de acordo com o ritual, são juntadas para se verificar a identidade do portador.

Na primeira parte da peça se revela - com o oráculo de Apolo e Tirésias e com os discursos de Édipo e Jocasta -, a verdade sobre o assassinato de Laio, e na

6 Para citações diretas e indiretas, tanto em português como em grego do texto de Sófocles, utilizaremos os números dos versos compatíveis com a obra: Sófocles (2012). Édipo-Rei de Sófocles. (Trad. T. Vieira, edição bilíngue Grego-Português). São Paulo: Perspectiva. 
segunda metade se juntam as partes sobre seu nascimento, com os testemunhos do mensageiro de Corinto e do pastor do Citerão. Mesmo cada uma dessas metades se subdivide em outras duas. No que se refere ao assassinato de Laio, acrescentam-se o relato de Édipo sobre como matou um desconhecido no caminho e, em seguida, a descoberta de que este desconhecido realmente é Laio. $\mathrm{O}$ relato sobre o nascimento também avança por partes: "teremos a metade paterna e logo a metade materna, até que o conjunto dos elementos reconstitua o conjunto da verdade" (Foucault, 2014, p. 214).

Com este esquema metodológico e quase matemático de Foucault (2014), o que se vê, então, é que partindo dos deuses, passando pelos reis e chegando até os escravos, o que há na peça é o excesso de saberes: saber da escuta e saber da visão; saber longínquo e saber da presença; saber dos reis e saber do fundo das cabanas dos escravos; saber da prescrição-predição e saber-testemunho; saber que se retira voluntariamente do enigma e saber que se esconde sob o medo e que somente a ameaça consegue extrair (pp. 211-212).

Entre o saber oracular de Tirésias e o saber-memória do escravo, "também Édipo é um homem do saber, de um saber muito particular que tem suas características, suas condições de exercício e seus efeitos" (Foucault, 2014, p. 220). Esse saber a meio-caminho, situado entre os deuses e os escravos é exatamente o do poder político, ou seja, o saber-poder tirânico. Por isso, o herói grego é, ao mesmo tempo, $\tau \dot{\varepsilon} \chi \gamma_{\eta}$ e $\tau \dot{\nu}$ pavvos, ou seja, alguém que desde seu saber específico, toma e perde o poder. Dessa maneira, Édipo-Rei deve ser considerada, antes de tudo, uma história do poder; uma fábula de como a descoberta de uma verdade "coloca em questão a própria soberania do soberano" (Foucault, 2002, p. 31).

Foucault (2002) delimita minuciosamente uma série de características da tirania, que se trata de uma forma de poder político surgida na Grécia entre os séculos VII e VI a.C e que no século V, com o surgimento do período clássico, encontra seu declínio (p. 50). Isso se confirma na conferência de 1972, quando ele observa que "a tirania de Édipo, a forma de poder que ele exerce, a maneira como o conquistou, não são marginais com relação à grande investigação empreendida: trata-se de uma maneira completamente central nas relações entre o poder e o saber" (Foucault, 2014, p. 220). Um ano depois, na segunda conferência realizada no Rio de Janeiro, ele será ainda mais explícito: "Podemos notar a importância da temática do poder no decorrer de toda a peça. Durante toda 
a peça o que está em questão é essencialmente o poder de Édipo e é isso que faz com que ele se sinta ameaçado" (Foucault, 2002, p. 41).

De acordo com o autor francês há ainda no texto de Sófocles uma série de passagens que mostram como esse poder edipiano é "posto em jogo e questionado" (Foucault, 2014, p. 220). Dos primeiros aos últimos versos, Édipo busca defender sua soberania, sem saber ainda aquilo que o destino reserva para ele. Vê-se isso, por exemplo, já no início da peça, quando os habitantes recorrem ao seu poder para salvar a cidade da peste (33-34), tendo a promessa de que ele fará todo o necessário, principalmente pela preservação de sua soberania para descobrir o assassino de Laio (139-140).

O embate com Tirésias, por sua vez, carrega a ambiguidade em relação ao poder. Enquanto é do alto de seu reinado e em vista da libertação da cidade que Édipo solicita a presença do adivinho cego, é esse mesmo poder real que é ameaçado pela profecia do duplo humano de Apolo (352). E na medida em que é acusado de assassinato, o que se vê por parte dele não é um discurso em defesa de sua inocência, mas sim a afirmação da força de seu poder (380-404).

No cerne do encontro de Édipo com Creonte (532-631), como recorda Foucault (2014), está "realmente o poder, só o poder - e não fatos, sinais ou provas" (p. 220). Por isso é que exatamente nesse momento o rei supõe um plano para tirá-lo do cargo que ocupa. O que se vê na sequência é uma série de gestos de poder, comum daqueles que têm autoridade suprema: está decidido inicialmente a cumprir a sentença de morte que acabara de pronunciar contra Creonte, para depois mostrar sua benevolência, ao aceitar o pedido de misericórdia vindo de Jocasta e do Coro (658-659 e 669-672).

Já nas cenas finais, depois de confirmar-se em sua glória frente ao mensageiro de Corinto, que revela que ele não é o filho consanguíneo de Políbio (1063), Édipo preside, como um "chefe de justiça", o interrogatório e a ameaça de tortura sobre o detentor da última parte do segredo, o pastor do Citerão. Após sua queda, lembra Foucault (2014, p. 235), as últimas palavras dirigidas a ele, antes de ser conduzido para fora do palácio real, se referem à interdição do novo rei Creonte: "Não queiras poder tudo" (1524).

Ao explorar a problemática do poder, Foucault redefine, também, a figura do tirano. Situado entre os deuses e a terra, ele ocupa uma posição frágil e perigosa como governante. Mesmo que todos lhe devam a salvação, por ter livrado a cidade 
da maldição da Esfinge, ele não é cidadão entre os outros. E se recebeu a ajuda dos deuses para vencer a divina cantora, mostra-se, no decorrer da peça, incapaz de fazer reinar sobre a cidade os decretos divinos. Como Foucault (2014) recorda na conferência de 1972 quanto ao destino de tirano, ele é "amado e depois rejeitado, depois causando piedade; obedecido em cada uma de suas vontades singulares, que valem como os decretos da cidade, depois banido e votado ao destino execrável quando a seu orgulho podem opor as leis formuladas pelos olímpicos" (p. 224).

É importante recordar que o tirano, no século $\mathrm{V}$ a. C., se situava num lugar ambíguo na medida em que apresentava, tanto no caráter como na forma de governo, traços positivos e negativos. Por isso mesmo, esta figura estava longe de ser considerada uma unanimidade entre seus concidadãos. $\mathrm{O}$ que se sabe é que boa parte do prestígio do tirano vinha do fato de que sua imagem se confundia com a dos heróis gregos. Na própria história de Édipo, por exemplo, não é difícil de identificar elementos comuns às fábulas mitológicas. Rejeitado de maneira hostil pelo pai, por causa de presságios anteriores ao seu nascimento, a criança é abandonada para morrer numa floresta, no mar ou no rio. Em alguns mitos, o verdadeiro pai é um deus. Na juventude, dá sinais de notáveis poderes. Quando cresce, realiza grandes obras, muitas vezes matando monstros. Por meio de seu talento, recupera o seu reino, ganha uma noiva, a figura do pai pune o mal, até que descobre e restaura seus pais perdidos. Da mesma forma, é o solucionador bem-sucedido de enigmas que está, por isso mesmo, sob pena de morte.

Mas certamente, a tirania continha um lado menos mítico. Sem hereditariedade, o tirano ascendia ao poder por uma via indireta. São suas proezas, sua sabedoria e seus atos que qualificam as suas conquistas. Como recorda Vernant, "ele reina não pela virtude de seu sangue, mas por suas próprias virtudes; ele é o filho de suas obras ao mesmo tempo em que da Boa Sorte" (1999a, p. 86). Por ser investido de poderes extraordinários, exatamente por conquistar de maneira incomum tudo o que possui, ocupava, por tempo determinado, o cargo de chefe absoluto da cidade.

Mas de longe isso significa que se tratava de alguém que contentava a todos. Em realidades conturbadas pelas disputas partidárias, era praticamente impossível encontrar uma pessoa que conciliasse as diferentes necessidades e desejos.

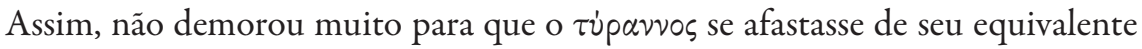


$\beta a \sigma i \lambda \varepsilon \dot{\zeta}$, adquirindo um caráter pejorativo. Isso principalmente por conta dos inimigos irreconciliáveis que essa forma de governo suscitou; pessoas contrárias aos detentores do poder absoluto, conquistado não pelo acordo legítimo entre os partidos, mas pela insurreição.

No intuito de controlar as possíveis rebelióes e protestos, em especial os dos mais pobres, o tirano acomodava as leis aos seus interesses particulares, garantindo que todas as suas ações fossem permitidas. Junto com isso, embelezava a cidade com enormes construções, tinha especial atenção para a questão agrária, que exigia solução rápida perante os camponeses, os quais com seu trabalho, garantiam a subsistência da população e ofereciam ao povo festas magníficas com concursos líricos e representações teatrais.

Mas é impossível negar que o tirano representava, sobretudo, uma figura de excessos e transgressões, já que é impossível desvincular esse tipo de governo daquilo que pode se considerar historicamente como o pior de todos os regimes, pois se fundava na violência e na elevação de um homem acima das leis. Um indício de que isso se confirma está nos versos do famoso e obscuro segundo estásimo de Édipo-Rei (863-910), cantado pelo Coro diante de uma plateia que a esta altura da peça já se mostra apreensiva com o desfecho da história. Tais versos têm provocado, de geração em geração de estudiosos, uma série de dificuldades de interpretação. O Coro, deixado sozinho por Sófocles no palco como uma parabasis, fala das leis eternas que ninguém pode violar sem receber, em troca, castigos violentos. Menciona injurias e violências de palavra e obra, além de soberba e de lascividades. Pronuncia ainda maldições contra os insolentes ultrajadores dessa lei eterna e termina com uma oração de louvor a Zeus e a seu domínio ante todas as coisas.

O que parece consenso para alguns estudiosos é que tais palavras repreendem a Édipo, condenando a desmesura do governante autoritário e déspota. Em seu reconhecido estudo, Édipo em Tebas, Bernard Knox (2002) recorda que o título

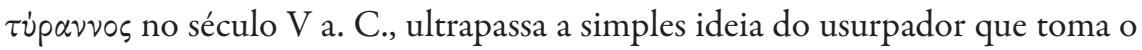
poder do rei hereditário. O tirano "era um aventureiro que, por mais brilhante e próspero que tenha sido seu regime, ganhara e mantivera o poder por violência" (p. 47). E é pela violência e pelo assassinato que Édipo chega ao poder.

O inglês Richard Jebb (1885), enfraquece, numa de suas notas analíticas acerca da peça, qualquer ideia que indique que a expressão $\tau$ ípavvos tem por 
função a simples substituição neutra à $\beta \alpha \sigma i \lambda$ ví. Para ele, o efeito que se tem com as palavras do Coro é exatamente o contrário, ou seja, há uma potencialização plena do sentido histórico e político do termo: "Aqui não se trata de um príncipe, nem mesmo no sentido usual grego, de um governante inconstitucionalmente absoluto (bom ou ruim), mas de um tirano, em nosso sentido" (p. 141).

$\mathrm{O}$ canto do Coro, situado precisamente no momento em que a fortuna e a sorte de Édipo começam a cair, simboliza para Foucault (2014, p. 223) a reviravolta do $\pi \lambda \tilde{\eta} \theta 0$; é a inversão da imagem positiva que até ali se tem do tirano e é igualmente o momento no qual ao seu reino se opõe os vópol, "leis - altos pés! - a fixam, geradas através do urânio éter" (865-867). Este estásimo é uma ode à origem, natureza e fim do tirano e revela os traços tradicionalmente atribuídos a essa figura, tais como presunção, injustiça, recusa de honrar os deuses, insolência culpável, ganhos injustos, sacrilégios, profanação das coisas santas, recusa de escutar os oráculos, abandono do culto. Se no primeiro estásimo o Coro claramente defende o seu amado rei ${ }^{7}$, neste que é posterior à discussão com Creonte, ele se

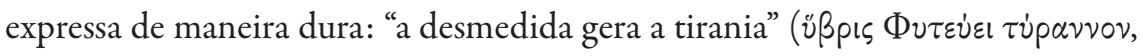
873). "É bem verdade que o Coro ainda sofrerá uma nova reviravolta e, uma vez concluída a desgraça, se apiedará daquele que, por um momento, possibilitara que a cidade respirasse" (Foucault, 2014, p. 223).

Curiosamente, num pequeno mas intrigante texto intitulado El estasimo segundo del Edipo Rey de Sófocles, de 1952, Ignacio Errandonea sustenta a tese de que o canto do Coro não se dirige a Édipo e ao seu governo. Para ele, levando em conta as manifestações de apreço e fidelidade que os cidadãos cantores pronunciaram ao seu amado governante até aquele momento da peça, seria contraditório que tais palavras, tão duras, fossem dirigidas a alguém que ainda não carregava consigo culpa alguma. Mas a quem então estão destinadas tão vigorosas advertências?

Para o jesuíta espanhol a resposta é simples: "o estásimo segundo de ÉdipoRei se refere a Laio e se refere somente a Laio” (Errandonea, 1952, p. 57; nossa tradução) $)^{8}$. E isso, de longe representa, para ele, uma imperfeição artística ou

\footnotetext{
7 "Conforme eu disse, rei, mais de uma vez, seria um desatino (e eu um sem tino) se abandonasse a quem de novo trouxe à prátria, imersa em dor, a boa brisa” (690-695). 
mesmo uma mudança de foco de Sófocles, que se poderia imaginar, passou de um personagem principal - Édipo - para um secundário - Laio. É exatamente a centralidade no "pecado anterior" de Laio que o torna o protagonista dos versos em questão. Para tanto, argumenta Errandonea que Eurípedes teria levado ao teatro, alguns anos antes da representação de Édipo-Rei, os dramas Enomao, Crísipo e As Fenícias, sendo que dos dois primeiros se conservaram apenas alguns fragmentos, mas suficientes para confirmar, juntamente com o último, que permaneceu intacto, que o público já considerava Laio culpável e castigado pelos seus ultrajes à Pélope (1952, p. 45).

Ainda que as descobertas de Errandonea não corroborem, por exemplo, com os argumentos de Jebb, Knox e mesmo de Foucault, de que Édipo é efetivamente o personagem central do canto do Coro nesse importante estásimo, entre eles se pode encontrar um aspecto comum: os versos se dirigem aos abusos cometidos pelo tirano e a essa forma de governo que, entre tantos excessos, violam as leis da pureza e da castidade, as leis da hospitalidade, as leis do respeito aos deuses tutelares do lugar, ao rei e à sua família, e as leis eternas da gratidão. Se Édipo certamente infringiu várias delas, Laio, por sua vez, com seu comportamento

9 Vernant (1999c) resume dessa forma o mito relacionado à maldição que recai sobre as gerações dos Labidácidas: “[...] Layo se enamora de Crisipo, un bellísimo muchacho que es hijo de Pélope. Lo corteja intensamente, lo pasea en su carro, se comporta como un hombre adulto respecto a otro más joven, le enseña a ser un hombre, pero al mismo tiempo intenta tener con él una relación erótica que el hijo del rey rechaza. Parece incluso que Layo se ha obstinado en conseguir por la fuerza lo que la seducción y el mérito no habían llegado a darle. Se cuenta también que Crisipo, indignado y escandalizado, se suicida. El caso es que Pélope dirige contra Layo una solemne maldición en la que pide que el linaje de los Labdácidas no consiga perpetuarse, que sea abocado a la aniquilación. El nombre de Lábdaco significa 'el cojo', y el nombre de Layo no es demasiado claro; puede querer decir que es un caudillo popular, o que es un hombre 'torpe'. Cabe observar, en efecto, que Layo estropea todas sus relaciones, a todos los niveles. Por una parte, desde el punto de vista de la sucesión, que a través de su padre Lábdaco, su abuelo Polidoro y su bisabuelo Cadmo, debería llevarle directamente y establecerle en el trono de Tebas. Ahora bien, Layo ha sido apartado, soslayado y alejado de él: la sucesión, por tanto, ha sido desviada. Layo presenta también otra desviación, ya que, a la edad en que podría pensar en casarse, se inclina hacia un muchacho. Pero, sobre todo, desvía el juego amoroso pretendiendo imponer con la violencia lo que Crisipo no está dispuesto a ofrecerle espontáneamente, no existe ninguna reciprocidad entre ellos, no hay intercambio amoroso. El impulso erótico, unilateral, está bloqueado. Además, Layo es el huésped de Pélope, y esta relación de hospitalidad supone una reciprocidad de amistad, de regalos y de contrarregalos. Lejos de corresponder a quien lo ha acogido, Layo intenta poseer a su hijo en contra de su voluntad y provoca su suicidio" (pp. 176-177). 
arrogante, violento e violador transgrediu a todas e, por isso mesmo, merece a condenação do Coro, que exige em seu canto pureza integral tanto nas palavras como nas obras, sempre de acordo com as leis imortais.

Esta hipótese adquire valor na medida em que se assume que Laio é, ele também, um tirano, como expressa Sófocles por três vezes $(128,799$ e 1043) e de que as palavras do Coro, "a desmedida gera a tirania" (873), estão exatamente dirigidas à incontinência dele. E somente tal violência, própria de uma figura sombria como Laio, seria capaz de gerar por filho esse 'desconhecido' que agora buscam, igualmente amaldiçoado pela desgraça que Pélope lançou sobre o clã dos Labdaciodos.

Ambas interpretações assinalam aquilo que é o mais execrável dos crimes do tirano: a prepotência diante dos deuses e de suas leis. Ao desobedecer as ordens do oráculo em não ter filhos, Laio expõe toda comunidade ao perigo da contaminação, contrariando dessa forma o que deve ser a primeira das responsabilidades de um rei ( $\beta \alpha \sigma i \lambda \varepsilon \dot{s} \varsigma)$ : proteger a ordem social. Ésquilo (2018), em Sete contra Tebas recorda que a resposta do oráculo à consulta de Laio foi a de que ele deveria morrer sem descendência para salvar a cidade (748-749), o que nos leva a entender, seguindo os passos do autor trágico, que foi uma escolha, e não uma necessidade conceber um filho. Tampouco ele é vítima das inexoráveis redes de maldição mas, pelo contrário, foi de sua natureza violenta e lascívia, inclusive entregando seu filho à morte no intuito de reparar a fratura por ele mesmo gerada, que derivou todo mal para Tebas.

Na personalidade de Édipo vemos o mesmo impulso de fugir daquilo que já estava determinado pelos deuses. $\mathrm{O}$ crime da prepotência se repete. $\mathrm{O}$ diálogo que se trava entre a rainha e seu filho-esposo, posicionado entre os dois estásimos é, sobretudo, um jogo argumentativo em que os reis justificam seus esforços para esgueirar-se das prediçóes oraculares. Jocasta narra de que forma entregou o herdeiro do trono de Tebas ao camponês para que fosse morto e Édipo, por sua vez, conta como fugiu às pressas de Corinto, a fim de que não se cumprisse a profecia de que mataria seu pai. São os relatos dos processos humanos que tentam, de todas as maneiras, modificar o destino já traçado.

Tanto o rei como a rainha se permitem negar os dois procedimentos de saber que ordenam o futuro. Primeiramente, aquele que consiste em procurar por meio de sinais obscuros o que cabe aos deuses esconder: "Mulher, qual o sentido de observar o recinto profético de Píton, as aves como ululam céu acima?” (964-965). 
Em segundo lugar, o procedimento que procura ver antecipadamente a parte do destino que foi fixada pelos deuses. "Fará sentido o padecer humano, se o Acaso impera e a previsão é incerta?” (977-978). É para nada que eles acreditam que estes decretos-predições podem levar: "Políbio tais oráculos consigo levou ao Hades, letra morta, nada" (971-972).

Foucault (2014) recorda que ao negar o procedimento oracular, Édipo escolhe outro tipo de saber a partir de um novo tipo de poder. É o recém-chegado procedimento jurídico, que tem em sua estrutura interna a necessidade de descobrir a verdade por si mesmo, sem a ajuda dos deuses. Não obstante, o que se vê neste processo é a anulação desse saber próprio de Édipo como tirano. No espaço da cidade, na qual tudo o que acontece está em consonância com os desejos do Olimpo, torna-se desnecessário qualquer tipo de governo. O que comanda esse território são as leis humanas que têm sua origem e seu fundamento na inspiração dos deuses. Os procedimentos legais fazem Édipo chegar nele mesmo e confirmam o que já estava escrito no destino. É nesta courbe soudaine que o saber-poder tirânico se apaga.

4. Da transgressão à pureza

Há NAS leituras foucaultianas desse período um denominador comum: a peça de Sófocles representa o exato momento do rompimento entre o poder e o saber, no qual este último passa a ser visto, desde então, “(...) em termos de justiça, de pureza, de 'desinteresse', de pura paixão por conhecer" (Foucault, 2014, p. 236). Por isso, o que se deve excluir do espaço da cidade, com os novos procedimentos judiciais é o poder tirânico, ou seja, o poder daquele que governa desde um saber específico, de uma $\tau \dot{\varepsilon} \chi \chi \eta$.

Na aula de 17 de março de 1971, Foucault se propõe a ler a tragédia de Édipo a partir da ligação originária e fundamental que, em nossa cultura, estabeleceuse entre saber, poder e pureza, $\dot{\alpha} \gamma v \varepsilon \varepsilon \tilde{\alpha} v$. A cidade está contaminada pelo crime cometido. Sua ordem, sua estabilidade econômica e social e, agora, a soberania que rege sua existência estão fragilizadas. Tebas sofre de um $\lambda$ oı ós, isto é, de um esgotamento das fontes de fecundidade: a terra, os rebanhos e as mulheres. Nada mais se gera, enquanto a peste dizima os seres vivos (25-27). Em seu território se veem somente doentes. A mancha, $\mu \alpha \sigma \mu \alpha$, se expressa tradicionalmente pela esterilidade, pela doença e pela morte, e somente a expulsão da polução da cidade 
resgatará o curso normal da vida. Essa condição deve-se, principalmente, ao fato de que a mancha foi causada por um homicídio, crime esse que, pela impureza que reveste o culpado e pela ameaça de contaminação da comunidade, é tido como um atentado contra os homens e contra os deuses (Glotz, 1980, p. 192).

O discurso do sacerdote na primeira cena, que apela para a ventura que reinava sobre Tebas antes do flagelo, nos dá uma ideia de como a pureza e a divindade são elementos intimamente ligados: Édipo é o libertador e o salvador, e em sua figura de rei concentram-se os poderes políticos e religiosos. Por isso, ele é considerado, ao mesmo tempo, o chefe de estado e o sumo-sacerdote. Venerado como um deus, as características quase divinas de sua imagem que avança para a entrada do palácio, são evidências de um ideal grego no qual o puro se confunde com o justo e o sagrado. "Édipo igual a um deus? Nem eu nem os meninos incorremos nesse equívoco; um ás te reputamos nas questôes de vida e no comércio com os deuses" (31-34).

O miasma $(\mu i \alpha \sigma \mu \alpha)$ impõe como condição uma série de rituais jurídicos, sociais e religiosos de restauração: é necessário saber se um crime foi cometido e por quem. O diálogo com o sacerdote é em torno da questão "o que se deve fazer", ainda que Édipo seja aquele que, diante da Esfinge, tenha respondido à pergunta pelo "quem" (Foucault, 2014, p. 167). Mais tarde, é o oráculo que, nas palavras de Creonte, retifica a questão recordando que "o que se deve fazer" é procurar "quem" (40-45). E não se trata de buscar o assassino para que se inicie um longo processo de purificação, mas antes, e principalmente, para que o criminoso seja exilado do espaço da cidade ou até morto. Foucault (2014) indica que não será Tirésias, pela parte do deus, que nomeará o culpado, apesar de fazê-lo de alguma maneira, mas serão os dois apavorados servos; aqueles que viram com seus próprios olhos e dos quais não se espera nenhuma sabedoria (p. 167).

É a verdade, pois, a única capaz de excluir a mancha da cidade; é ela que restabelece a realidade dos fatos; ela é o que permite excluir e separar o que está perigosamente misturado; ela é o que divide o interior do exterior; é ela que determina os limites entre o puro e o impuro; ela é a única passagem legítima da impureza ao que deve eliminá-la. Dessa forma, a verdade passa a incorporar os grandes rituais jurídicos, religiosos, morais, requeridos pela cidade, pois uma cidade sem verdade é uma cidade ameaçada pelas misturas, pelas exclusões não acabadas. A verdade torna-se assim a condição primeira ou, em todo caso, primordial da purificação (Foucault, 2014, p. 168). 
Mas qual é, para Foucault, a mancha que o rito da verdade deve restabelecer no Édipo? A falta que atinge o impuro está em ignorar uma lei que na cidade está publicada e visível para todos e que se projeta na própria ordem da natureza. Voluntária ou involuntariamente, ele não obedece o vónos. Seus olhos estão fechados e sua mancha é característica de um ävouos. O vónos são as leis que, distante da revelação divina, se constituem em algo tão somente humano. A elas

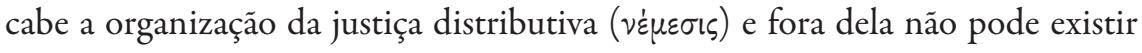
ordem ( $\dot{\eta} \gamma \grave{\alpha} \rho \tau \dot{\alpha} \xi ı$ vónos) (Aristóteles, 1998, 1287a). Trata-se de um domínio reconhecido pela coletividade e que significa, etimologicamente, um princípio de repartição. Como salienta Foucault, "a pureza é condição para ter acesso à lei: para ver a ordem das coisas e para poder proferir o vónos. Esse lugar mediano que, como vimos, é o lugar fictício em que se coloca o legislador, como Sólon, esse lugar mediano, apenas quem for puro pode ocupar" (Foucault, 2014, p. 169). Aquele que governa deve ser puro, uma vez que somente ele é capaz de dizer e ver o vónos como desdobramento da ordem social.

O que relaciona então, para Foucault, pureza e impureza à ordem social é o saber. Para que a pureza reine novamente sobre a cidade, é preciso que a verdade seja restabelecida. Na medida em que o crime produz a mancha e esta atinge a totalidade do território, torna-se necessário conhecer quem cometeu o homicídio e puni-lo. E isso exige uma investigação. A verdade transforma-se então numa tarefa política, na qual a impureza e seus efeitos têm como exigência a procura do que se passou. No Édipo-Rei, somente a descoberta da verdade tem o poder de purificar, restabelecendo a ordem perdida pelo crime cometido. E se outrora foi Édipo quem respondeu ao enigma da Esfinge e endireitou (óp $\theta$ ós) ${ }^{10}$ a cidade, agora é ele mesmo, o impuro, que permanece cego ao vónos mais fundamental: de conhecer sua ascendência. Suas manchas, ou seja, o assassinato e o incesto, impedem-no de ver o que é preciso ser feito: "ele não sabe mais qual é a ordem das coisas e a ordem humana” (Foucault, 2014, p. 169).

Com isso, Foucault sinaliza para um deslocamento do saber no interior da peça: do palácio imperial às cabanas do Citerão. Édipo deve buscar fora de seu espaço de soberano as respostas às suas perguntas. E a cada novo movimento de

10 Ver Édipo-Rei (2012), números 39, 46, 50, 51. 
saber e a cada novo fragmento de verdade que se encaixa à téssera, mais um pedaço de poder edipiano vai sendo tomado. Aquele cujo saber-poder sustentava a cidade é agora incapaz de saber e igualmente incapaz de governar.

Há, dessa forma, para Foucault, tanto em Sófocles - como em Platão -, uma desqualificação do poder que se liga a um saber específico, combatendo a tentativa dos tiranos e dos sofistas de reabilitarem a sobreposição do poder com a $\tau \dot{\varepsilon} \chi \nu \eta$ ou a do poder mágico religioso comum às civilizações orientais, em especial nos impérios assírios. Trata-se de uma clara resistência ao modelo social no qual o soberano detinha o poder da mântica, da justiça e da vida política.

A tragédia de Édipo nada mais é, então, que o ponto de emergência de um longo processo de decomposição que foi se estabelecendo na Grécia acerca da relação entre saber e poder. Ela é o exato momento em que a política se divorcia do saber, para dar origem então ao homem do poder revestido de ignorância: "cego, que não sabia e não sabia porque poderia demais” (Foucault, 2002, p. 50). O que Platão instaura é um movimento de antinomia entre saber e poder, no qual se valoriza o contato com os deuses e as lembranças contidas na memória, mas nunca a figura do político: "o homem do poder e do saber, aquele que dominava tanto pelo poder que exercia quanto pelo saber que possuía” (Foucault, 2002, p. 49).

Diante dos excessos de Édipo e seu poder em demasia, pode-se afirmar com Foucault que há uma nova compreensão de política a partir do século $\mathrm{V}$ a. C. Juntamente com a imagem do rei sábio, que sustenta, governa, pilota, endireita a cidade e a livra da peste e da fome, e a sua versão rejuvenescida, o tirano, que salva a cidade, mas o faz desviando-se do oráculo dos deuses, o que desaparece com a história edipiana é o saber-poder ligado às transgressões e às lutas. E o que aparece no seu lugar é uma noção de poder relacionada diretamente com a pureza, com o desinteresse e com a vontade inocente de conhecer. Não há mais, desde a saga edipiana, a verdade no poder político; este é tido como ignorante, obscuro e cego.

\section{Considerações finais}

Foucault nos mostra, em suas análises da década de 1970, que Édipo-Rei é o ponto de eclosão para as formas de saber-poder que se estabeleceram no ocidente. Nesse sentido, trata-se para ele, de denunciar a vontade de saber que emerge de um modelo judiciário recém implantado e que impõe, por um lado, que a 
verdade, por meio do inquérito, seja algo visível e mensurável e, por outro, que essa mesma verdade esteja relacionada com a ideia de pureza e de ordem do mundo. Ou seja, o detentor do poder, aquele que governa a cidade, deve ser aquele capaz de acessar a verdade por um tipo de saber que se constitui "em termos de justiça, de pureza, de desinteresse, de pura paixão por conhecer" (Foucault, 2014, p. 236).

Nesse desmantelamento entre o poder político e o saber, o que desaparece com Édipo-Rei é a figura do tirano. Esse governante que é supernumerário do saber, detentor de um poder político e de um saber especial que se correlacionam, mas que, desde então, exatamente pela tentativa de escapar dos decretos dos deuses, torna-se incapaz de manter na cidade a "ordem do mundo". E o que se constrói para Foucault, como grande mito ocidental, a partir de Sófocles mas principalmente de Platão, é que o poder político não é detentor da verdade, pois este é cego e inconsciente, e que o verdadeiro saber é esse que emerge da memória profunda, "quando olhamos o grande sol eterno e abrimos os olhos para o que se passou” (2002, p. 51). E se há um convite de Foucault para pensar o presente é precisamente esse, que para ele Nietzsche começa a demolir, "que por trás de todo saber, de todo conhecimento, o que está em jogo é uma luta de poder. O poder político não está ausente do saber, ele é tramado com o saber" (2002, p. 51).

\section{Referências bibliográficas}

Aristóteles (2004). Poética. (Trad. A. M. Valente). Lisboa: Calouste Gulbenkian. Chaves, E. (2014). Prefacio à edição brasileira. In: J. Allouch, A psicanálise é um exercicio espiritual? Resposta a Michel Foucault (pp. 11-25). (Trad. M. R. Salzano Moraes e P. S. de Souza Jr.). Campinas: Editora da Unicamp.

Deleuze, G. (2003). Pourparlers 1972-1990. Paris: Editions de Minuit.

Deleuze, G. \& Guattari, F. (1972). L'Anti-Oedipe. Capitalisme et schizophrénie. Paris: Minuit.

Detienne, M. (1967). Les Maîtres de Vérité dans da Grèce archä̈que. Paris: François Maspero.

Errandonea, I. (1952). El estásimo segundo del Edipo Rey de Sófocles. Ciudad Eva Perón (LaPlata): Instituto de Lenguas Clásicas.

Ésquilo. (2018). Sete contra Tebas. (Trad. T. Vieira). São Paulo: Editora 34. 
Foucault, M. (1999). Microfísica do poder. (Trad. R. Machado). Rio de Janeiro: Edições Graal.

Foucault, M. (2002). A verdade e as formas juridicas. (Trad. R. Machado; E. Morais). Rio de Janeiro: Nau Editora.

Foucault, M. (2008). Le gouvernement de soi et des autres. Cours au Collège de France. 1982-1983. Paris: Gallimard, Seuil.

Foucault, M. (2012a). Du gouvernement des vivants. Cours au College de France.1979-1980. Paris: Gallimard, Seuil.

Foucault, M. (2012b). Mal faire, dire vrai. Fonction de l'aveu en justice. Louvain: Presses Universitaires de Louvain.

Foucault, M. (2014). Aulas sobre a vontade de saber. Curso no Collège de France (1970-1971). (Trad. R. C. Abílio). São Paulo: WMF Martins Fontes.

Gernet, L. (1968) Droit et institutions en Grèce antique. Paris: Flammarion.

Glotz, G. (1980). A cidade grega. (Trad. H. A. Mesquita e R.Cortes de Lacerda). São Paulo: DIFEL.

Jaeger, W. (1953). Alabanza de la ley: los origenes de la filosofía del derecho y los griegos. Revista de Estudios Políticos, 26(67), 17-48.

Jebb, R. C. (1885). The Oedipus Tyrannus. Cambrigde: Cambridge University Press.

Knox, B. (2002). Édipo em Tebas. (Trad. M. Goldsztajn). São Paulo: Perspectiva. Nietzsche, F. (1988). Nachgelassene Fragmente 1869-1874. Band 7. Berlim: Walter de Gruyter.

Nietzsche, F. (1992). O nascimento da tragédia. (Trad. J. Guinsburg). São Paulo: Companhia das Letras.

Nietzsche, F. (2006). Introdução à tragédia de Sófocles. (Trad. E. Chaves). Rio de Janeiro: Jorge Zahar Editor.

Sforzini, A. (2015). Scènes de la vérité. Michel Foucault et le théâtre. Philosophie. (Tese de doutorado). Université Paris-Est, 2015. (Sem publicar). Revisado em https://tel.archives-ouvertes.fr/tel-01281743/document.

Sófocles (2012). Édipo-Rei de Sófocles. (Trad. T. Vieira, edição bilíngue Grego -Português). São Paulo: Perspectiva.

Vernant, J.-P. (1999a). Ambiguidade e reviravolta. Sobre a estrutura enigmática de Édipo-Rei In: J.-P. Vernant \& P. Vidal-Naquet, Mito e tragédia na Grécia 
Antiga (pp. 73-99). (Trad. A. L.A. de Almeida; F. Y. H. Garcia). São Paulo: Perspectiva.

Vernant, J.-P. (1999b). Édipo sem complexo. In: J.-P. Vernant \& P. Vidal-Naquet, Mito e tragédia na Grécia Antiga (pp. 53-71). (Trad. A. L.A. de Almeida; F. Y. H. Garcia). São Paulo: Perspectiva.

Vernant, J.-P. (1999c). Érase una vez... El universo, los dioses, los hombres. (Trad. D. Zadunaisky). México, D.F.: Fondo de Cultura Económica.

Vidal-Naquet, P. (1999). Édipo em Atenas. In: J.-P. Vernant \& P. Vidal-Naquet, Mito e tragédia na Grécia Antiga (pp. 267-285). (Trad. A. L.A. de Almeida; F. Y. H. Garcia). São Paulo: Perspectiva. 